\title{
Model Regresi Data Panel Terbaik untuk Faktor Penentu Laba Neto Perusahaan Asuransi Umum Syariah di Indonesia
}

\author{
Delia Fatharani Durrah ${ }^{1, a)}$, Rini Cahyandari ${ }^{1, b)}$, Asep Solih Awalluddin ${ }^{1, c)}$ \\ ${ }^{1} J u r u s a n$ Matematika, Fakultas Sains dan Teknologi, UIN Sunan Gunung Djati Bandung \\ a)email: deliafd98@gmail.com \\ ${ }^{b}$ email: rcahyandari@yahoo.com \\ c)email: aasolih@gmail.com
}

\begin{abstract}
Abstrak
Data panel merupakan gabungan antara data cross section dengan data time series. Model regresi data panel terbaik pada penelitian ini adalah Random Effect Model (REM). Faktor penentu laba neto $(Y)$ yang diteliti yaitu biaya klaim $\left(X_{1}\right)$, pendapatan investasi neto $\left(X_{2}\right)$, hasil underwriting $\left(X_{3}\right)$, dan pendapatan premi neto $\left(X_{4}\right)$. Hasil uji kecocokan model untuk mengetahui faktor penentu laba neto perusahaan asuransi umum syariah di Indonesia menunjukkan bahwa biaya klaim, hasil underwriting, dan pendapatan premi neto mempengaruhi laba neto perusahaan asuransi umum syariah di Indonesia selama periode pengamatan tahun 2014-2017.

Kata kunci: Data Panel, Random Effect Model (REM), Biaya Klaim, Hasil Underwriting, dan Pendapatan Premi Neto
\end{abstract}

\begin{abstract}
Panel data is a combination of cross section data with time series data. The best panel data regression model in this study is the Random Effect Model (REM). Determinants of net profit $(Y)$ studied were claim costs $\left(X_{1}\right)$, net investment income $\left(X_{2}\right)$, underwriting results $\left(X_{3}\right)$, and net premium income $\left(X_{4}\right)$. Model fit test results to determine the determinants of net profit of sharia general insurance companies in Indonesia show that claim costs, underwriting results, and net premium income affect net profit of sharia general insurance companies in Indonesia during the 2014-2017 observation period.

Keywords: Panel Data, Random Effect Model (REM), Claim Costs, Underwriting Results, and Net Premium Income

\section{Pendahuluan}

Asuransi adalah salah satu usaha yang dilakukan oleh peserta untuk dapat melindungi suatu hal atau barang dari kerugian maupun musibah yang dapat terjadi di kemudian hari. Perusahaan asuransi berfungsi untuk memberikan layanan berupa jasa dalam menanggulangi kemungkinan terjadinya risiko tersebut kepada masyarakat [1]. Proses operasional serta transaksi yang ada di dalam sistem asuransi syariah dilarang bertentangan dengan ketentuan yang diharamkan oleh Allah.
\end{abstract}


Perusahaan asuransi umum dengan sistem syariah dibagi menjadi dua bagian yaitu prinsip syariah dan unit syariah. Pertumbuhan jumlah industri asuransi umum syariah setiap tahun pengamatan terdapat pada tabel 1 berikut.

Tabel 1. Pertumbuhan Industri Asuransi Umum dengan Prinsip Syariah Tahun 2014-2017

\begin{tabular}{lcccc}
\hline Keterangan & 2014 & 2015 & 2016 & 2017 \\
\hline $\begin{array}{l}\text { Perusahaan Asuransi Umum dengan Prinsip Syariah } \\
\begin{array}{l}\text { Perusahaan Asuransi Umum yang Memiliki Unit } \\
\text { Syariah }\end{array}\end{array}$ & 23 & 24 & 24 & 25 \\
\hline
\end{tabular}

Sumber: Statistik Perasuransian Indonesia (Otoritas Jasa Keuangan)

Bertambahnya jumlahindustri dari asuransi umum prinsip syariah dan unit syariah membawa pengaruh positif terhadap perusahaan asuransi sebagai penyedia layanan asuransi. Semakin banyak masyarakat yang tertarik pada produk asuransi diharapkan laba perusahaan juga meningkat.Untuk menghasilkan laba, perusahaan mengelola dana yang ada dari kontribusi peserta secara hati-hati. Contohnya, yaitu dengan melakukan pembayaran klaim peserta, melakukan investasi secara syariah, serta mengelompokan risiko yang akan ditanggung oleh perusahaan asuransi melalui proses underwriting dengan tepat.

Penelitian dilakukan untuk mengetahui apakah empat faktor seperti biaya klaim, pendapatan investasi neto, hasil underwriting, dan pendapatan premi neto menentukan laba netoperusahaan asuransi umum syariah di Indonesia atau tidak selama tahun 2014-2017. Data pada penelitian menggunakan data panel. Untuk mengetahui faktor penentu laba neto dibutuhkan analisis regresi data panel. Pada analisis regresi dengan data panel, menggunakan tiga jenis model estimasi data yaitu Common Effect Model, Fixed Effect Model, dan Random Effect Model yang kemudian akan dipilih sebagai model estimasi terbaik.

Sebagaimana penjelasan mengenai latar belakang tersebut penulis melakukan penelitian dengan judul "Model Regresi Data Panel Terbaik untuk Faktor Penentu Laba Neto Perusahaan Asuransi Umum Syariah di Indonesia".

\section{Metode}

1. Identifikasi Variabel

a) Variabel Dependen (Terikat)

Variabel dependen pada penelitian ini adalah laba neto $(Y)$ yang digunakan sebagai ukuran pendapatan neto perusahaan.

Laba yaitu selisih perolehan pendapatan selama transaksi yang dilakukan perusahaan pada periode tertentu kemudian dikurangi pengeluaran biaya transaksi.

b) Variabel Independen (Bebas)

Variabel independen pada penelitian ini yaitu,

-Biaya Klaim $\left(X_{1}\right)$ : Biaya klaim adalah kompensasi yang dibayarkan atau liabilitas kepada perusahaan asuransi jika terjadi kerugian, terdiri dari klaim reasuransi, estimasi klaim retensi sendiri, dan klaim bruto. 
-Pendapatan Investasi Neto $\left(X_{2}\right)$ : Pendapatan bersih yang diperoleh dari kegiatan investasi yang dilakukan oleh perusahaan asuransi.

-Hasil Underwriting $\left(X_{3}\right)$ : Pengukuran hasil underwriting didasarkan pada perbedaan antara pendapatan underwriting dikurangi dengan beban underwriting.

-Pendapatan Premi Neto $\left(X_{4}\right)$ : Pendapatan yang diperoleh dari kontribusi peserta di dalam asuransi syariah.

2. Metode Penelitian

Jenis penelitian adalah penelitian kuantitatif, dengan menggunakan data sekunder berupa data laporan keuangan tahunan perusahaan yang telah diterbitkan selama tahun pengamatan. Populasi pada penelitian ini yaitu perusahaan sektor asuransi umum (kerugian) syariah di Indonesia menggunakan metode purposive sampling. Kriteria untuk mendapatkan sampel adalah sebagai berikut:

a) Perusahaan asuransi umum syariah yang diamati yaitu dengan prinsip syariah dan yang memiliki unit usaha syariah yang terdaftar di Otoritas Jasa Keuangan (OJK) tahun 2014-2017.

b) Setiap tahun pengamatan, laporan keuangan selalu disajikan oleh perusahaan tersebut serta menyajikan data yang dibutuhkan selama pengamatan.

3. Metode Estimasi Model Regresi Data Panel

Terdapat tiga metode yang digunakan untuk mengestimasi model regresi data panel yaitu:

a) Ordinary Least Square (OLS)

Metode OLS memberikan estimasi dari $\beta_{0}$ dan $\beta_{1}$ secara unik sehingga memberikan kemungkinan nilai error kuadrat terkecil [2].

b) Least Square Dummy Variable (LSDV)

Metode LSDV tidak berbeda jauh dengan metode OLS atau Ordinary Least Square, yaitu dengan meminimumkan dan melakukan turunan pertama fungsi kuadrat error.

c) Generalized Least Square (GLS)

Metode GLS dilakukan dengan mentransformasikan variabel-variabel asli, dengan memenuhi asumsi klasik dan menerapkan metode Ordinary Least Square (OLS) pada variabel yang sudah ditransformasikan [13].

4. Model Regresi Data Panel dan Estimasi Parameter

a) Common Effect Model

Common Effect Model adalah model yang paling sederhana karena hanya menggabungkan data cross section dan time series. Sehingga, perbedaan nilai antara cross section dan time series diabaikan [4]. Bentuk model regresi Common Effect Model yakni,

$$
Y_{i t}=\beta_{0}+\beta_{1} X_{1 i t}+\beta_{2} X_{2 i t}+\cdots+\beta_{k} X_{k i t}+u_{i t}
$$

Common Effect Model diestimasi menggunakan metode Ordinary Least Square (OLS). Bentuk estimasi parameter Common Effect Model sebagai berikut,

$$
\hat{\beta}_{O L S}=\left(X^{\prime} X\right)^{-1} X^{\prime} Y
$$

b) Fixed Effect Model

Individualitas masing-masing perusahaan (individu), dapat dihitung pada Fixed Effect Model dengan membuat variasi pada intersep untuk setiap perusahaan dan koefisien slope diasumsikan konstan. Bentuk model regresi Fixed Effect Model yakni [5], 


$$
Y_{i t}=\beta_{0 i}+\beta_{1} X_{1 i t}+\beta_{2} X_{2 i t}+\cdots+\beta_{k} X_{k i t}+u_{i t}
$$

Perbedaan setiap individu pada intersep $\left(\beta_{0 i}\right)$ yaitu dengan menggunakan variabel dummy. Maka bentuk persamaan Fixed Effect Model (FEM) menjadi:

$$
Y_{i t}=\beta_{0 i} D_{i t}+\beta_{1} X_{1 i t}+\beta_{2} X_{2 i t}+\cdots+\beta_{K} X_{K i t}+u_{i t}
$$

Fixed Effect Model diestimasi menggunakan metode Least Square Dummy Variable (LSDV). Bentuk estimasi parameter Fixed Effect Model sebagai berikut,

c) Random Effect Model

$$
\hat{\beta}=\left(X^{\prime} Q X\right)^{-1}\left(X^{\prime} Q Y\right)
$$

Random Effect Model melibatkan korelasi antar error term karena berubahnya waktu maupun unit observasi. Perbedaan nilai intersep dari setiap perusahaan tercermin dalam error $\mu_{i}$. Bentuk model regresi Random Effect Model yakni [3],

$$
Y_{i t}=\beta_{0 i}+\beta_{1} X_{1 i t}+\beta_{2} X_{2 i t}+\cdots+\beta_{k} X_{k i t}+v_{i t}
$$

Koefisien $\beta_{0 i}$ diasumsikan sebagai variabel acak dengan nilai rerata $\beta_{0}$. Nilai intersep untuk individu yakni:

$$
\beta_{0 i}=\beta_{0}+\mu_{i} \quad i=1,2, \ldots, N .
$$

Random Effect Model diestimasi menggunakan metode Generalized Least Square (GLS). Bentuk estimasi parameter Random Effect Model sebagai berikut [6],

$$
\hat{\beta}_{G L S}=\left(X^{\prime} \Omega^{-1} X\right)^{-1} X^{\prime} \Omega^{-1} Y
$$

5. Uji Spesifikasi Model

Terdiri dari tiga uji spesifikasi model yang dilakukan untuk mengetahui model regresi data panel terbaik yaitu,

a) Uji Chow

Uji Chow dilakukan untuk memilih antara Common EffectModel sebagai $\left(H_{0}\right)$ dan Fixed EffectModelsebagai $\left(H_{1}\right)$. Rumus untuk menghitung uji Chow yakni,

$$
F_{\text {hitung }}=\frac{\left(E S S_{R}-E S S_{U}\right) /(N-1)}{E S S_{U} /((T-1) N-k)}
$$

b) Uji Hausman

Uji Hausman digunakan dalam memilih antara Fixed EffectModel (FEM) sebagai $H_{0}$ dan Random EffectModel (REM) sebagai $H_{1}$. Statistik uji Hausman adalah sebagai berikut,

$$
m=\hat{q}^{\prime}[\operatorname{var}(\hat{q})]^{-1} \hat{q}
$$

c) Uji Lagrange Multiplier

Uji Lagrange Multiplier (LM) digunakan untuk memilih antara Random Effect Model sebagai $H_{0}$ dengan Common Effect Model sebagai $H_{1}$. Statistik uji Lagrange Multiplier,

$$
L M=\frac{N T}{2(T-1)}\left[\frac{\sum_{i=1}^{N}\left(T \tilde{u}_{i}\right)^{2}}{\sum_{i=1}^{N} \sum_{t=1}^{T} \tilde{u}_{i t}^{2}}-1\right]^{2}
$$

\section{Hasil dan Diskusi}

Terdapat 19 perusahaan asuransi umum syariah di Indonesia yang diteliti tahun 2014-2017 yaitu PT Asuransi Takaful umum, PT Asuransi Chubb Syariah Indonesia, PT Asuransi Adira Dinamika, PT Asuransi Allianz Utama Indonesia, PT Asuransi Bangun Askrida, PT Asuransi Bintang Tbk, PT Asuransi Bringin 
Sejahtera Arthamakmur, PT Asuransi Central Asia, PT Asuransi Parolamas, PT Asuransi Ramayana Tbk, PT Asuransi Sinar Mas, PT Asuransi Staco Mandiri, PT Asuransi Tri Pakarta, PT Asuransi Umum Bumiputera Muda 1967, PT Asuransi Umum Mega, PT Tugu Pratama Indonesia, PT Asuransi Kresna Mitra Tbk, PT Asuransi Wahana Tata, dan PT Pan Pacific Insurance.

Untuk memilih model estimasi regresi data panel terbaik pada pengamatan perlu dilakukan uji spesifikasi model yang terdiri dari uji Chow, uji Hausman, dan uji Lagrange Multiplier sebagaimana tertera pada tabel 2 berikut.

Tabel 2. Uji Spesifikasi Model Regresi Data Panel

\begin{tabular}{lcc}
\hline \multicolumn{1}{c}{ Uji Chow } & Uji Hausman & Uji Lagrange Multiplier \\
\hline$F_{\text {hitung }}(11.218)>$ & $\rho-$ value $(0.8106)>0.05$ & $\rho-$ value $\left(9.477 \times 10^{-11}\right)$ \\
$F_{\text {tabel }}(1.802)$ & Terpilih: Random Effect Model & $>0.05$ \\
Terpilih: Fixed Effect Model & & Terpilih: Random Effect Model \\
\hline
\end{tabular}

Maka bentuk model regresi data panel Random Effect Model (REM) dengan 19 perusahaan yang diobservasi selama empat tahun pada pengamatan ini adalah sebagai berikut:

$$
\begin{aligned}
& \hat{Y}_{i t}=\sum_{i=1}^{19} \sum_{t=1}^{4} \beta_{0 i}+\sum_{i=1}^{19} \sum_{t=1}^{4} \beta_{1 i t} X_{1 i t}+\sum_{i=1}^{19} \sum_{t=1}^{4} \beta_{2 i t} X_{2 i t}+\sum_{i=1}^{19} \sum_{t=1}^{4} \beta_{3 i t} X_{3 i t}+\sum_{i=1}^{19} \sum_{t=1}^{4} \beta_{4 i t} X_{4 i t} \\
& \text { atau dapat dituliskan sebagai, } \\
& \hat{Y}_{i t}=\beta_{0 i}+1.03600 X_{1 i t}+0.29146 X_{2 i t}+1.25631 X_{3 i t}-0.95444 X_{4 i t}
\end{aligned}
$$

Nilai intersep Random Effect Model (REM) setiap perusahaan yang diteliti pada pengamatan ini bervariasi. Perbedaan nilai intersep ini menunjukkan bahwa setiap perusahaan memiliki nilai laba neto yang berbeda-beda. Hasil output besar nilai intersep setiap perusahaan yang diteliti pada Random Effect Model (REM) yang disajikan pada tabel 3 berikut.

Tabel 3. Nilai Intersep Perusahaan Random Effect Model

\begin{tabular}{cccc}
\hline Perusahaan & Nilai Intersep & Perusahaan & Nilai Intersep \\
\hline A & -20495.9172 & K & 28517.5593 \\
B & -11395.1593 & L & -1435.5912 \\
C & 4095.3153 & M & 3134.8734 \\
D & -1383.0741 & N & -2519.6429 \\
E & 261.0373 & O & 4554.2805 \\
F & 3548.7367 & P & 1119.7812 \\
G & -2364.4695 & $\mathrm{Q}$ & -2324.8657 \\
H & -145.1089 & R & -3526.2014 \\
I & -3027.6664 & S & -1916.2098 \\
J & 5302.3229 & & \\
\hline
\end{tabular}


Berdasarkan hasil output Random Effects Model (REM) dapat disimpulkan bahwa:

1. Terdapat hubungan positif antara biaya klaim, pendapatan investasi neto, dan hasil underwriting dengan laba neto. Dengan demikian jika biaya klaim, pendapatan investasi neto, dan hasil underwriting meningkat maka laba neto juga meningkat.

2. Terdapat hubungan negatif antara pendapatan premi neto dengan laba neto. Dengan demikian jika pendapatan premi neto menurun maka laba neto juga menurun.

3. Pendapatan investasi neto tidak memiliki pengaruh terhadap laba neto. Hal ini dapat terjadi karena tujuan kegiatan investasi adalah untuk memperoleh pendapatan, sedangkan hasil dari kegiatan investasi tidak dapat dipastikan. Sedangkan biaya klaim dan hasil underwriting memiliki pengaruh yang signifikan terhadap laba neto. Biaya klaim yang harus dikeluarkan selama tahun pengamatan masih dalam batas wajar, sehingga laba yang dihasilkan semakin besar. Hasil underwriting selama tahun pengamatan mampu menutupi beban underwriting, maka terdapat surplus underwriting. Sehingga semakin tinggi hasil underwriting mempengaruhi besar laba neto perusahaan asuransi.

4. Sedangkan, pendapatan premi neto memiliki pengaruh yang signifikan terhadap laba neto. Hal ini dapat terjadi karena setiap premi yang dibayarkan oleh peserta memiliki unsur risiko. Jika risiko terjadi semakin besar maka jumlah laba yang dihasilkan semakin menurun.

5. Jika biaya klaim bertambah sebanyak satu poin maka, laba neto akan bertambah sebanyak 1.03600 poin. Jika pendapatan investasi neto bertambah sebanyak satu poin, maka laba neto akan bertambah sebanyak 0.29146 poin. Jika hasil underwriting bertambah sebanyak satu poin maka, laba neto akan bertambah sebanyak 1.25631 poin. Jika pendapatan premi neto bertambah sebanyak satu poin, maka laba neto akan berkurang sebanyak 0.95444 poin. Asumsi bahwa variabel bebas yang lain pada model regresi konstan.

6. Tanpa dipengaruhi oleh biaya klaim, pendapatan investasi neto, hasil underwriting, dan pendapatan premi neto, rata-rata laba neto adalah dengan asumsi variabel lain konstan.

Uji hipotesis dilakukan untuk mengetahui apakah Random Effect Model (REM) pada regresi data panel signifikan seperti pada tabel 4 berikut.

Tabel 4. Uji Hipotesis

\begin{tabular}{lll}
\hline & \multicolumn{1}{c}{ Uji Hipotesis } \\
\hline Koefisien Determinasi & \multicolumn{1}{c}{ Uji $F$} & \multicolumn{1}{c}{ Uji $t$} \\
$R^{2}=0.31227$ & $F_{\text {hitung }}(8.05676)>$ & 1. $\left|t_{\text {hitung }}\right|$ Biaya Klaim $3.4414>$ \\
& $F_{\text {tabel }}(2.50076)$ & $t_{\text {tabel }}(1.66660)$ \\
& $2 .\left|t_{\text {hitung }}\right|$ Pendapatan Investasi \\
& Neto $1.4489<t_{\text {tabel }}(1.66660)$ \\
& $3 .\left|t_{\text {hitung }}\right|$ Hasil Underwriting \\
& $3.57648>t_{\text {tabel }}(1.66660)$ \\
& $4 .\left|t_{\text {hitung }}\right|$ Pendapatan Premi Neto \\
& $3.14654>t_{\text {tabel }}(1.66660)$ \\
\hline
\end{tabular}


Pengaruh biaya klaim, pendapatan investasi neto, hasil underwriting, dan pendapatan premi neto di dalam model dapat menjelaskan laba neto sebesar $31.227 \%$. Sedangkan $68.773 \%$ sisanya dijelaskan oleh variabel lain diluar model yang tidak diteliti. Biaya klaim, pendapatan investasi neto, hasil underwriting, dan pendapatan premi neto secara simultan mempengaruhi laba neto perusahaan asuransi umum syariah di Indonesia dengan faktor yang berpengaruh terhadap laba neto perusahan Asuransi umum syariah di Indonesia selama periode pengamatan tahun 2014-2017 adalah biaya klaim, hasil underwriting, dan pendapatan premi neto.

\section{Kesimpulan}

Kesimpulan pada penelitian ini adalah sebagai berikut:

1. Model regresi data panel Random Effect Model (REM) terpilih sebagai model regresi data panel terbaik untuk mengetahui faktor-faktor penentu laba neto perusahaan asuransi umum syariah di Indonesia.

2. Hasil uji kecocokan model mendapatkan kesimpulan bahwa biaya klaim, hasil underwriting, dan pendapatan premi neto mempengaruhi laba neto perusahaan asuransi umum syariah di Indonesia selama periode pengamatan tahun 2014-2017.

\section{Ucapan Terima Kasih}

Penulis mengucapkan terima kasih kepada Jurusan Matematika dan pihak-pihak lain yang ikut berperan serta dalam penelitian ini.

\section{Referensi}

[1] A. Rahmawati, "Kinerja Keuangan dan Tingkat Pengembalian Saham: Studi pada Perusahaan Asuransi di Bursa Efek Indonesia,"Jurnal Bisnis dan Manajemen, vol. 7, pp. 1-14, April 2017.

[2] D. N. d. D. C. P. Gujarati, Dasar-Dasar Ekonometrika Buku 1, 5 ed., D. A. Halim, Ed., Jakarta: Salemba Empat, 2012.

[3] D. N. Gujarati, Basics Econometrics, 4th Edition ed., New York: McGraw-Hill/Irwin, 2003.

[4] Widarjono, Ekonometrika Teori dan Aplikasi Untuk Ekonomi dan Bisnis, Yogyakarta: Ekonosia, 2007.

[5] M. T. d. M. A. Ijomah, "Fixed Effect Versus Random Effects Modelling in a Panel Data Analysis; A Consideration of Economic and Political Indicators in Six African Countries," International Journal of Statistics and Applications, pp. 275-279, 2017.

[6] T.D.d.R.L.Wright,"Pooling Cross-Sectional and Time Series Data- A Review of Statistical Estimation Techniques," Januari 1977. 